\title{
The potential of recycling wool residues as an amendment for enhancing the physical and hydraulic properties of a sandy loam soil
}

\author{
Ahmed Abdallah $^{1}$ (1) - Francesca Ugolini ${ }^{2}$ - Silvia Baronti ${ }^{2}$. Anita Maienza ${ }^{2} \cdot$ Francesca Camilli $^{2} \cdot$ Laura Bonora $^{2}$. \\ Francesca Martelli ${ }^{2} \cdot$ Jacopo Primicerio $^{2} \cdot$ Fabrizio Ungaro $^{2}$
}

Received: 26 February 2019 / Accepted: 19 June 2019 / Published online: 27 June 2019

(c) The Author(s) 2019

\begin{abstract}
Purpose Climate change and global food demand in coming decades urge effective actions for more efficient uses of water and soil resources. This paper reports the preliminary findings of a study assessing the potential of sheep scoured wool residues (SWRs) as soil amendments to enhance the physical and hydraulic properties of a sandy loam soil under rain conditions. Methods Two different SWRs were used: scoured residues (white wool, WW) and carbonized scoured residues (black wool, BW) at different SWRs/soil ratios (0.0, 0.5, 1.0 and 2.0\%). Soil bulk density (BD), total porosity (TP), aggregates stability, aggregate size distribution, saturated hydraulic conductivity, and water retention properties were determined under rain conditions, in addition to rainwater balance (storage, percolation and runoff).

Results Both WW and BW, particularly at the high wool/soil ratio (2\%), significantly reduced soil BD by $11.98 \%$ and $9.85 \%$, respectively. Moreover, WW and BW increased TP by $16.45 \%$ and $13.57 \%$ and available water capacity by $6.5 \%$ and $18.1 \%$, respectively. SWRs increased the formation of macro-aggregates and increased aggregate stability. The results of rainwater balance showed higher percolation percentages and less rainwater storage in the wool-treated soil.

Conclusions The increase in water percolation is in line with the increased total porosity and the higher saturated hydraulic conductivity of wool-treated soil. Despite the high capacity of absorbing water, SWRs affected the water movement of the soil more than its water retention.
\end{abstract}

Keywords Sheep wool residues $\cdot$ Soil physical properties $\cdot$ Soil functions $\cdot$ Rainwater

\section{Introduction}

Frequent drought events due to climate change and global food demand in the coming decades urge effective actions for a more efficient use of natural resources (FAO 2015; Lee et al. 2017; Wasaya et al. 2018). Soil organic matter $(\mathrm{OM})$ plays an important role in the regulation of soil water-dynamics by enhancing soil physical characteristics (structure, porosity, water retention, permeability) (de Melo

Ahmed Abdallah

ph7@damanhour.edu.eg

1 Department of Natural Resources and Agricultural Engineering, Faculty of Agriculture, Damanhour University, 59, Damanhour, Egypt

2 CNR IBiMet, National Research Council of Italy, Institute of Biometeorology, Via G. Caproni 8, 50145 Florence, Italy et al. 2019), and in promoting microorganisms (Williams et al. 2016; Minasny and McBratney 2018; Ghosh and Devi 2019). An increase in soil organic carbon (OC) often leads to an increase in crop yield (Alagöz and Yilmaz 2009; Oguntade et al. 2018; Ben Mbarek et al. 2019) and can mitigate the effects of climate change by storing $\mathrm{CO}_{2}$ in the soil (Williams et al. 2016; Minasny and McBratney 2018). Agricultural and agro-industrial wastes are the most commonly used OM sources used as soil amendments (Rigby et al. 2015). However, little is known about the potential of industrial sheep wool residues (SWRs) that could also contribute to increasing the economic and environmental sustainability of sheep wool supply chain.

Keratin, the wool protein, is known to slowly degrade into simpler compounds, releasing nutrients in the soil over a long period (Zheljazkov 2005; Bhavsar et al. 2016). Besides the high carbon content (50\%), wool residues are known to stimulate plant growth and yield (Zheljazkov 2005; 
Zheljazkov et al. 2008; Ordiales et al. 2016) thanks to the high content of several nutritional elements such as nitrogen (16-17\%) and sulfur (3-4\%) (Verville 1996). Hydrolyzed wool has been successfully used as a fertilizer for plants (McNeil et al. 2007). Other studies demonstrated that undecomposed wool products could be successfully used as valuable nutrient sources for both container-grown plants and field crops (Zheljazkov et al. 2008, 2009).

Given the biodegradability, nutrient content and water absorption properties, wool residues seem to have high potential as ecofriendly amendments (Zoccola et al. 2015). Some studies reported that they can effectively absorb and retain moisture (Murray et al. 2000; Mubarak et al. 2009; Zoccola et al. 2015), thus facilitating water conservation. On the other hand, as these residues are very light and low-density materials (Jaroszuk and Słowińska-Jurkiewicz 2005; Nowak 2005), they could reduce soil bulk density and modify air-water relations. Such effects influence the hydraulic conductivity and lead to deeper drainage and less water storage. However, little is known on the hydraulic and physical properties of wool-soil mixtures, and there is no comprehensive study in the literature on the physical effects of wool as soil amendment. This study aimed at investigating the changes in soil physical properties, i.e., water retention properties, Ksat), available water capacity (AWC), bulk density (BD), total porosity (TP), aggregate size distribution (ASD), aggregate stability and infiltration capacity of a sandy loam soil after the application of different SWRs under rainfall conditions.

\section{Material and methods}

\section{Soil characteristics}

The soil used in this study was collected with an auger from the Ap horizon $(0-30 \mathrm{~cm})$ in an olive orchard in southern Tuscany (Lat. $42^{\circ} 55^{\prime} 49.81^{\prime \prime} \mathrm{N}$, Long. $10^{\circ} 46^{\prime} 00.11^{\prime \prime} \mathrm{E} ; 15 \mathrm{~m}$ a.s.l.). The chemical, physical and hydraulic properties of the soil are shown in Table 1. The soil, formed on Pleistocene terraced deposits, is deep with an Ap-Bw-C profile, scarcely gravelly, weakly to moderately structured, with texture from clay loam to sandy loam (Soil Survey Division Staff 2017). It is non-calcareous (total carbonates: $<0.5 \%$ ), almost neutral (pH: 6.68), well drained and classified as a fine loamy, mixed, thermic, Eutric Cambisols (Soil Survey Staff 2014). The topsoil is poor in organic carbon $(0.44 \%)$, and nitrogen $(0.08 \%)$. The field saturated hydraulic conductivity of the Ap horizon was measured with a constant-head Guelph permeameter (Soilmoisture Equipment Corp. 2012). The Guelph permeameter is an in-hole constant-head permeameter employing the Marriott principle (Reynolds et al. 1983). The method measures the steady-state rate of water recharge
Table 1 Chemical, physical and hydraulic properties of the topsoil used in the experiment

\begin{tabular}{|c|c|}
\hline Parameters (unit of measurement) & Value \\
\hline $\mathrm{pH}$ & 6.68 \\
\hline Electrical conductivity (saturated extract) $\left(\mathrm{dS} \mathrm{m}^{-1}\right)$ & 0.705 \\
\hline Salinity $\left(\mathrm{mg} \mathrm{L}^{-1}\right)$ & 451 \\
\hline Total organic carbon (TOC) (\%) & 0.44 \\
\hline Total nitrogen $(\%)$ & 0.08 \\
\hline $\mathrm{C} / \mathrm{N}$ & 5.73 \\
\hline Total carbonates $\left(\mathrm{CaCO}_{3}\right)(\%)$ & $<0.5 \%$ \\
\hline Active carbonates $\left(\mathrm{CaCO}_{3}\right)(\%)$ & $<0.1 \%$ \\
\hline Available $\mathrm{P}\left(\mathrm{P}_{2} \mathrm{O}_{5}\right)\left(\mathrm{mg} \mathrm{kg}^{-1}\right)$ & 9.9 \\
\hline Exchangeable potassium $\left(\mathrm{K}_{2} \mathrm{O}\right)\left(\mathrm{mg} \mathrm{kg}^{-1}\right)$ & 232 \\
\hline Exchangeable calcium $(\mathrm{CaO})\left(\mathrm{mg} \mathrm{kg}^{-1}\right)$ & 927 \\
\hline Exchangeable magnesium $(\mathrm{MgO})\left(\mathrm{mg} \mathrm{kg}^{-1}\right)$ & 114 \\
\hline Exchangeable sodium $(\mathrm{Na})\left(\mathrm{mg} \mathrm{kg}^{-1}\right)$ & 43,4 \\
\hline Cations exchange capacity (CEC) $\mathrm{Cmol} \mathrm{kg}^{-1}$ & 5.6 \\
\hline$\%$ Exchangeable Na (ESP) & 3.4 \\
\hline Bulk density, fallow $\left(\mathrm{M} \mathrm{m}^{-3}\right)$ & $1.17 \pm 0.09$ \\
\hline Bulk density, olive orchard $\left(\mathrm{M} \mathrm{m}^{-3}\right)$ & $1.58 \pm 0.05$ \\
\hline Sand content $(\%)$ & 67.6 \\
\hline Silt content $(\%)$ & 15.2 \\
\hline Clay content $(\%)$ & 17.8 \\
\hline USDA textural class & Sandy loam \\
\hline Field Ksat $\left(\mathrm{mm} \mathrm{h}^{-1}\right)$ & $97.2 \pm 44.9$ \\
\hline $\mathrm{VG}^{\mathrm{a}}$ Theta $\mathrm{r}\left(\mathrm{m}^{3} \mathrm{~m}^{-3}\right)$ & $0.146 \pm 0.006$ \\
\hline $\mathrm{VG}^{\mathrm{a}}$ Theta $\mathrm{s}\left(\mathrm{m}^{3} \mathrm{~m}^{-3)}\right.$ & $0.472 \pm 0.048$ \\
\hline $\mathrm{VG}^{\mathrm{a}}$ air entry $1 / \alpha(\mathrm{cm})$ & $18.78 \pm 1.41$ \\
\hline $\mathrm{VG}^{\mathrm{a}} n$ & $2.12 \pm 0.05(-)$ \\
\hline $\mathrm{VG}^{\mathrm{a}} m=1-1 / n$ & $0.528 \pm 0.01(-)$ \\
\hline Available water capacity $\left(\mathrm{m}^{3} \mathrm{~m}^{-3}\right)$ & $0.352 \pm 0.04$ \\
\hline
\end{tabular}

${ }^{a}$ VG, water retention parameters calculated using Van Genuchten's model (1980)

into unsaturated soil from a cylindrical well hole in which a constant depth (head) of water is maintained. The permeameter is generally operated at two heads, namely 5 and $10 \mathrm{~cm}$.

The soil retention properties were measured on three soil cores using a sand bath (tensions from 0 to $10 \mathrm{kPa}$ ) and a pressure plate apparatus (tensions from 33 to $1500 \mathrm{kPa}$ ). The retention curves were parametrized resorting to the Van Genuchten model (Van Genuchten 1980).

\section{Sheep wool residues (SWRs) analysis}

The SWRs, derived from the first wool-processing phase (the scouring process, regulated by the Commission Regulation (EU) No 1063/2012), were provided by a wool scouring company (Carbofin S.r.1.) located in Vernio, Prato, Tuscany, Italy. Two types of SWRs were tested. The "white wool" residue (WW) was obtained by the mechanical beating of 
the scoured wool and formed of wool fiber residues and vegetal residues. The "black wool" residue (BW) was produced after the "carbonization" process to remove cellulosic impurities from the beaten wool with sulfuric acid $\left(\mathrm{H}_{2} \mathrm{SO}_{4}\right)$ and further beating. Both the WW and $\mathrm{BW}$ have a lint appearance (Fig. 1). To determine $\mathrm{C}$ and $\mathrm{N}$ contents, dry samples of wool residues (WW and BW) were analyzed using a CHN Elemental Analyzer (Carlo Erba Instruments, mod 1500 series 2 ). The dry samples were also digested in nitric and hydrofluoric acid (3:1) in a microwave oven (CEM, MARSXpress) according to the EPA method 3052 (US EPA 1996). Macro- and microelements were detected through an ICP-OES spectrophotometer (IRIS Intrepid II XSP Radial, Thermo Fisher Scientific).

\section{SWRs-soil mixtures}

The soil collected from the olive orchard was mixed with the wool residues at the experimental site of the Italian National Research Council (CNR) in Florence (Lat. $43^{\circ} 49^{\prime} 02.70^{\prime \prime} \mathrm{N}$, Long. $11^{\circ} 46^{\prime} 12.05 .26^{\prime \prime} \mathrm{E} ; 41 \mathrm{~m}$ a.s.1.). Each SWR was mixed with the dry soil using an electric mixer (120-L capacity, $500 \mathrm{~W}$ power electric concrete mixer; mixing time set to $30 \mathrm{~min}$ at a speed of 30 r.p.m.) to ensure a homogenous SWR-soil mixture. Three concentrations per SWR type were tested (WW0.5\%, WW1\%, WW2\% and BW0.5\%, BW1\%, BW2\%) and compared to the control (C). The proportions of WW and BW were made on the basis of their nitrogen content since SWRs were considered not only as soil amendments, but also as possible fertilizers. Both SWRs contain $8.2 \% \mathrm{~N}$, therefore $3.75,7.5$ and $15 \mathrm{~kg} \mathrm{~N} \mathrm{ha}^{-1}$ were applied, corresponding to $0.5,1$ and $2 \%$ of SWRs as treatments.

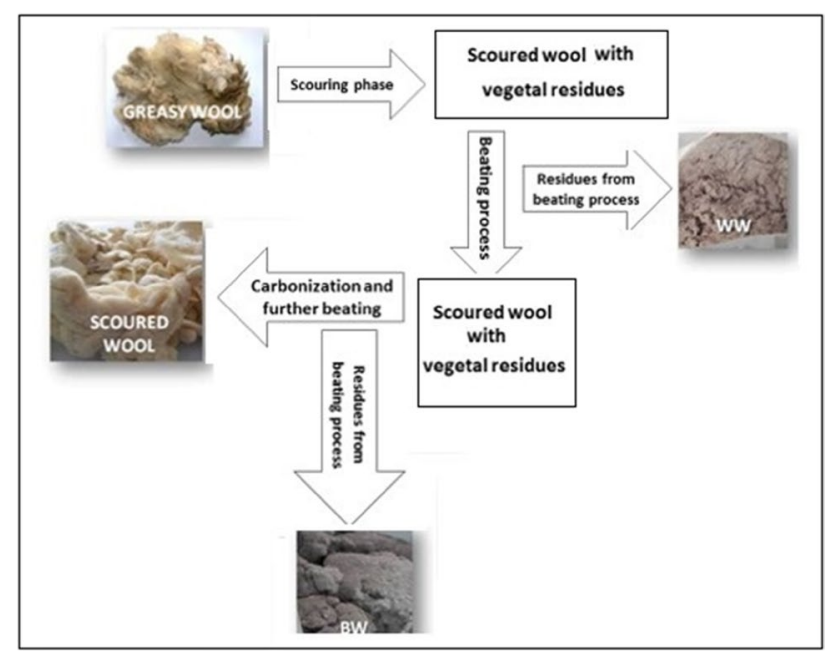

Fig. 1 Stages of the processing phase (scouring) in which the two types of industrial sheep wool residues (SWRs) are produced. $W W$ white wool residue, $B W$ black wool residue
Pots of $0.03 \mathrm{~m}^{3}$ volume (diameter $40 \mathrm{~cm}$, height $33 \mathrm{~cm}$, perforated from the bottom) were filled with the soil mixtures and control in six replicates. They were arranged in a completely randomized distribution, outdoor at ambient conditions throughout the experiment period (from January to July 2017).

\section{Analysis of some soil physical and hydraulic properties}

\section{Bulk density (BD) and total porosity (TP)}

In March, undisturbed soil samples of $100 \mathrm{~cm}^{3}$ (core method) were collected from three pots in each soil treatment and control to measure BD as dry weight in the given volume. The total porosity (TP) was estimated using the following equation, assuming a constant particle density of $2.65 \mathrm{Mg} \mathrm{m}^{-3}$ (Danielson and Sutherland 1986):

$\mathrm{TP}=1-\frac{\mathrm{BD}}{\mathrm{PD}}$

\section{Water retention curves}

In March, soil cores were sampled at 5-10 $\mathrm{cm}$ depth from three pots in each treatment and control to determine the soil water retention curves. Samples were saturated overnight. The measurements of water contents were performed at the following matric potential of: $0,10,50,100,330,1000$, and $15,000 \mathrm{~cm}$. The soil water retention curves were determined on the soil samples using a sand bath apparatus in the matric potential range from 0 to $-20 \mathrm{kPa}$ and a tension plate apparatus in the range from -20 to $-1500 \mathrm{kPa}$. The water content at each pressure step was calculated from the volume of the outflow, i.e., between the initial and final weight of the measured soil sample.

The experimental water retention curves were interpolated with the RETC software (Retention Curve Program for Unsaturated Soil) according to Van Genuchten et al. (1991) using the Van Genuchten model (1980) in order to derive the retention parameters, (i.e., air entry potential, pore size distribution index) for treatments comparison (Table 3). Field capacity (FC) and permanent wilting point (PWP) were also assessed for each treatment, and the available water capacity (AWC) was calculated on the basis of the difference between the FC and PWP.

\section{Saturated hydraulic conductivity}

Ksat also was measured in March in three pots, using the constant-head Guelph permeameter as described above. Given the pot size, the depth of the borehole $(12 \mathrm{~cm})$ and the heights of the steady ponded head of water, the distance 
between the (semi-) impermeable layer (i.e., the bottom of the pot) and the bottom of the auger hole was sufficiently large for these measurements, according to Hayashi and Quinton (2004).

\section{Slaking and aggregate stability}

Slaking and aggregate stability tests were conducted on the six mixtures and control according to the USDA (1999) in July. Aggregate size distribution (ASD) was determined by the standard dry-sieving method (Savinov 1936). The dry mean weight diameter (dMWD, $\mathrm{mm}$ ) was calculated according to Hillel (2004) as:

$\mathrm{dMWD}=\sum_{I=1}^{n} \mathrm{xi}$ wi,

where 'wi' is the weight percentage of each aggregate size class (ASC) with respect to the total sample and ' $x i$ ' is the mean diameter of each ASC (mm).

\section{Rainwater balance and soil water storage}

To study the effect of the two SWRs on soil water storage, drainage and runoff (rainwater balance), four soil mixtures (WW1\%, WW2\%; BW1\%, BW2\%) and control (C) were newly prepared at the end of March to fill three new replicates (same size pots used for the analysis described above). Pots were arranged outdoor in a completely randomized block design distribution outdoors at ambient conditions. The pots were left under rain-fed conditions (from April to June 2017). A rain-secured saucer was placed at the bottom of each container to collect the drained water after possible rain event. In order to collect the runoff water, a plastic tube was placed on the soil surface and connected to a $1.5-\mathrm{L}$ plastic bottle aside the pot. Only three rainfall events $(23.4 \mathrm{~mm}$ on April 28; $27.8 \mathrm{~mm}$ and $3.8 \mathrm{~mm}$ on May 7 and 9) were strong enough to generate water drainage and runoff. The meteorological parameters were provided by a weather station next to the experimental site.

\section{Salinity and pH of soil and leachate}

After each rainfall event and at the end of the experiment, water volumes were measured and leachate samples were collected. The electrical conductivity (EC, $\left.\mathrm{dS} \mathrm{m}^{-1}\right)$ and $\mathrm{pH}$ analysis of the leachate were measured. Moreover, EC and $\mathrm{pH}$ of soil were measured in three replicates, three times (at the beginning, at the first and third month of the experiment) on 1:2.5 soil:water extracts using a portable meter (PC7, Hydro Tech, Rosolini).

\section{Statistical analysis}

The statistical analysis was performed using the Statistica $64 \mathrm{v} .12$ software (StatSoft Inc 2014). The distribution of the measured parameters was formerly assessed using the Shapiro-Wilk test. Once normality had been checked, ANOVA test was performed followed by Tukey's honest significant difference to compare the mean values $(P<0.05)$. $T$ test between independent samples was used for the comparisons between two independent samples (for instance in the case of soil $\mathrm{EC}$ and $\mathrm{pH}$ at the beginning and end of the experiment).

\section{Results and discussion}

\section{Wool residues characterization}

The chemical analysis of the two SWRs used in this study is shown in Table 2. WW and BW carbon contents were 44.7 and $41.3 \%$, respectively, $\mathrm{N}$ and $\mathrm{H}$ contents were almost similar in the two SWRs while the $\mathrm{C} / \mathrm{N}$ ratio was slightly higher in WW. It is well established that wool residues retain considerable amount of $\mathrm{P}, \mathrm{Ca}, \mathrm{K}, \mathrm{Cu}, \mathrm{Zn}$, and $\mathrm{Mn}$ (Böhme et al. 2008; Suruchi et al. 2014; Zheljazkov et al. 2009). With respect to the WW, the carbonization treatment greatly affected the contents of $\mathrm{P}(-86 \%), \mathrm{K}(-75 \%), \mathrm{Mg}(-64 \%)$, $\mathrm{Ca}(-57 \%), \mathrm{Na}(-53 \%)$ and $\mathrm{S}(+203 \%)$. The decrease of $\mathrm{P}, \mathrm{K}, \mathrm{Mg}, \mathrm{Ca}$ and Na percentages in the BW is likely to be related to the effect of sulfuric acid on the vegetal parts of the WW residue.

\section{Bulk density (BD) and total porosity (TP)}

Results show that both BD and TP (Fig. 2) were more affected by SWRs concentration than by the type of residue.

Table 2 Chemical analysis of the two sheep wool residues used in this study

\begin{tabular}{lll}
\hline $\begin{array}{l}\text { Parameters } \\
\text { (unit of measurement) }\end{array}$ & WW & BW \\
\hline Organic C (\%) & 44.7 & 41.3 \\
$\mathrm{H}(\%)$ & 6.5 & 6.1 \\
Total N (\%) & 8.2 & 8.3 \\
$\mathrm{C} / \mathrm{N}$ & 5.5 & 5.0 \\
$\mathrm{Ca}\left(\mathrm{mg} \mathrm{kg}^{-1}\right)$ & 5856 & 2519 \\
$\mathrm{~K}\left(\mathrm{mg} \mathrm{kg}^{-1}\right)$ & 4416 & 1113 \\
$\mathrm{Mg}\left(\mathrm{mg} \mathrm{kg}^{-1}\right)$ & 1761 & 641.9 \\
$\mathrm{Na}\left(\mathrm{mg} \mathrm{kg}^{-1}\right)$ & 2684 & 1263 \\
$\mathrm{P}\left(\mathrm{mg} \mathrm{kg}^{-1}\right)$ & 1015 & 141.3 \\
$\mathrm{~S}\left(\mathrm{mg} \mathrm{kg}^{-1}\right)$ & 11,130 & 33,740 \\
\hline
\end{tabular}

$W W$ non-carbonized or white wool residue and $B W$ carbonized or black wool residue 

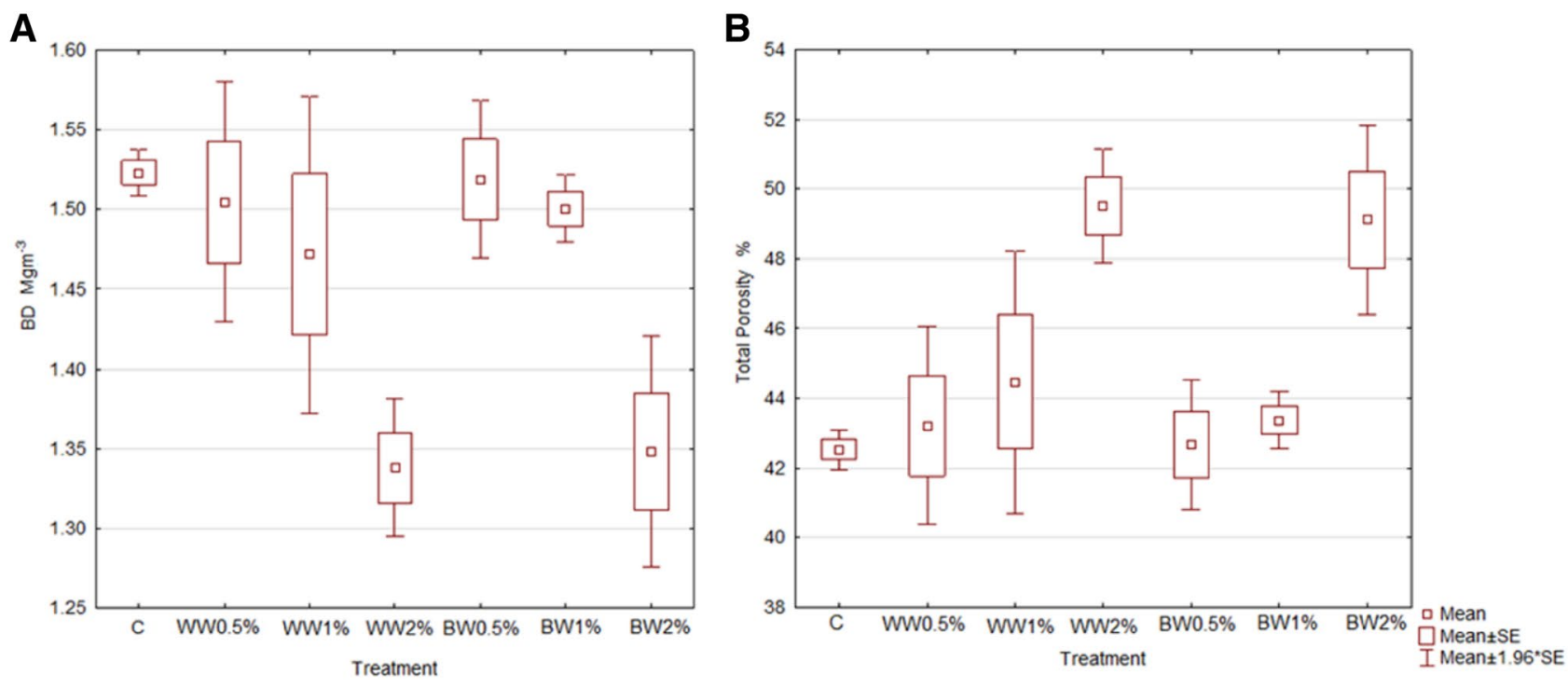

Fig. 2 Bulk density (BD, $\mathrm{Mg} \mathrm{m}^{-3}$ ) (a) and total porosity (TP, \%) (b) of the control soil (C) and SWR-soil mixtures (WW and BW residues) at $0.5,1$ and $2 \%$ concentrations. Average values $(n=3) \pm$ standard error, \pm 97.5 percentile point are shown

BD (Fig. 2a) decreased significantly $(P<0.05)$ only at the highest concentrations $(2 \%)$ by about $12 \%$ in WW-soil mixture and $10 \%$ and in $\mathrm{BW}$-soil mixture with values of $1.44 \pm 0.063 \mathrm{Mg} \mathrm{m}^{3}$ and $1.46 \pm 0.060 \mathrm{Mg} \mathrm{m}^{-3}$, respectively, when compared to the control $\left(1.52 \pm 0.015 \mathrm{Mg} \mathrm{m}^{-3}\right)$. In terms of TP, regardless of SWRs type, the results (Fig. 2b) showed a significant $(P<0.05)$ increase of about $16.5 \%$ and $13.6 \%$ for the WW and $\mathrm{BW}$, respectively, in the $2 \%$ treatment as compared to the control. The reduction in $\mathrm{BD}$ of SWRs-soil mixtures might be attributed to the presence of wool materials with very-low density (Jaroszuk and Słowińska-Jurkiewicz 2005; Nowak 2005). Basically, when BD decreases, TP increases. Kay (1998) reported a $\mathrm{BD}$ reduction from dilution of the soil matrix with a less dense organic material. Moreover, the BD reduction and TP increase are due to the formation of larger and more waterstable aggregates in SWRs-soil mixtures (as explained in detail below) as found by Mellek et al. (2010) and Franzluebbers (2002).

\section{Water retention curves}

Figure 3 shows the average water retention curves for the WW- (Fig. 3a) and BW- (Fig. 3b) soil mixtures. In the case of WW-soil mixtures, differences were evident at saturation in all treatments, with a maximum of $6 \%$ observed in the WW $1 \%$ treatment; $4.2 \%$ and $1.6 \%$ in WW2\% and WW0.5\% treatment, respectively. By increasing matric potential, the average difference in volumetric water content $\left(\mathrm{WC}_{\mathrm{V}}\right)$ with respect to the control became negative or negligible in the $0.5 \%$ treatment, while it was positive in the $1 \%$ and much higher in the $2 \%$ treatments (between 50 and $1000 \mathrm{~cm}$ matric potential) (Fig. 4a). In the case of BW-soil mixtures, no significant differences were observed at any matric potential. However, $\mathrm{WC}_{\mathrm{V}}$ in all treatments, at saturation, were higher than in the control treatment (Fig. 4b). In the BW2\% treatment, differences in $\mathrm{WC}_{\mathrm{V}}$ were equal to $8.2 \%$ and $3.4 \%$ at saturation and at $10 \mathrm{~cm}$ matric potential, respectively, but they dropped below $1 \%$ along with the retention points above $50 \mathrm{~cm}$ potential.

The increase in water content at saturation, FC and AWC of SWRs-amended soil confirmed the finding by Minasny and McBratney (2018) who performed a metaanalysis of 60 published studies and more than 50,000 measurements to seek relationships between organic carbon and water content at saturation, FC, and PWP. The authors found that the addition of OM mainly increases water content at saturation, followed by FC and PWP. In the current study, such increases could be attributed to the absorption properties of SWRs showing water retention that reduces the soil drying and therefore, minimizing the erosion risk (Zoccola et al. 2015). The results also agree with the findings of Murray et al. (2000) and Mubarak et al. (2009) that indicate an increase in water holding capacity (WHC) of the soil when wool carbon is applied because of the higher imbibition capacity. Contrarily to our results, Zheljazkov et al. (2009) reported that when wool was used as a growth media constituent, it did not change the WHC. In terms of AWC, in our study an increase was observed in the 1 and $2 \%$ treatments regardless of the SWRs-soil mixtures type (Table 3). This increase was equal to 7.2 and $6.5 \%$ in the case of the WW-soil mixtures at 1 and $2 \%$, respectively, and to 9.2 and $18.1 \%$ in the case of BW-soil mixtures at the same concentrations. 

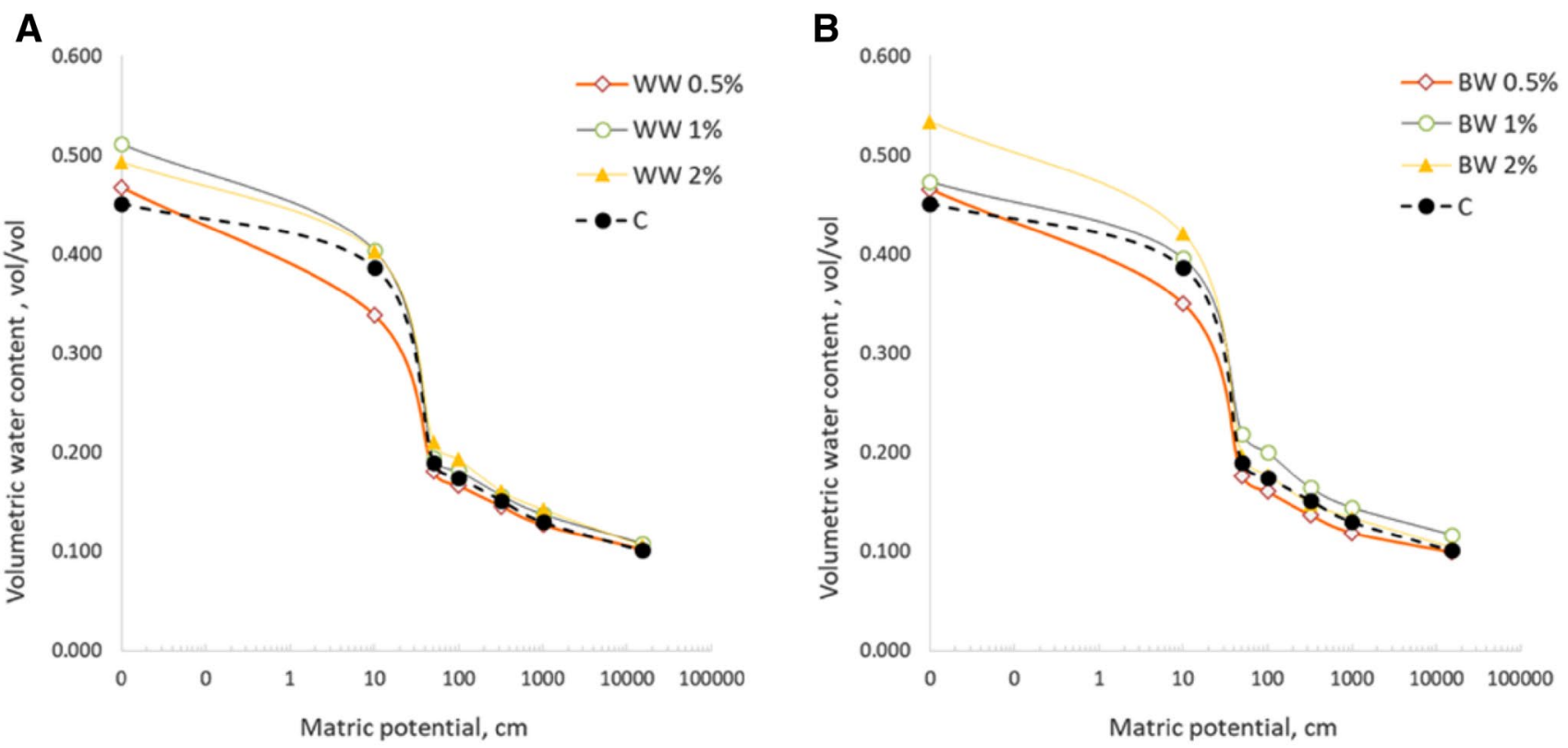

Fig. 3 Average water retention curves $(n=3)$ of the treatments. a WW-soil mixtures at $0.5,1$ and $2 \%$ concentrations and C, control; b BW-soil mixtures at $0.5,1$ and $2 \%$ concentrations and $\mathrm{C}$ (control)

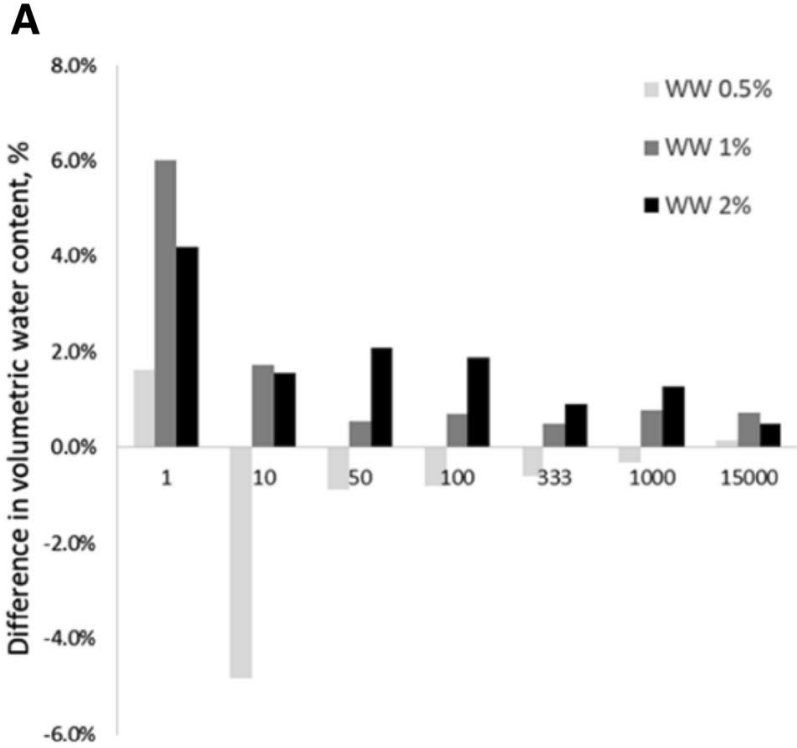

Matric potential, $\mathrm{cm}$
$\mathbf{B}_{10.0 \%}$

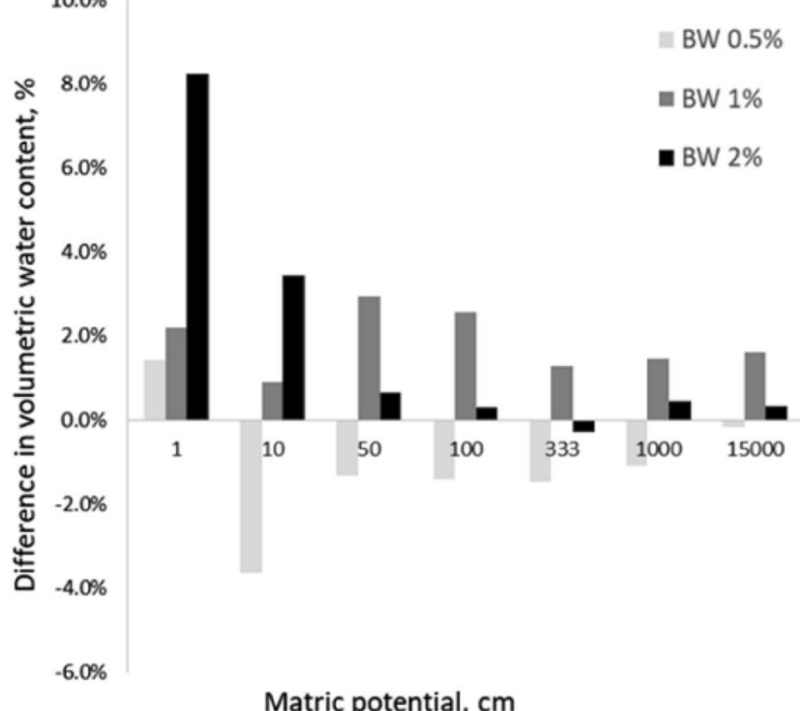

Matric potential, $\mathrm{cm}$

Fig. 4 Water retention curves. Difference in volumetric water content $\left(\mathrm{WC}_{\mathrm{V}}\right)$ at different matric potentials with respect to control for: a WW-soil mixtures at $0.5,1$ and $2 \%$ concentrations; $\mathbf{b}$ BW-soil mixtures at $0.5,1$ and $2 \%$ concentrations

The increase in AWC (at 1 and 2\% SWRs) observed in this study, is in agreement with the meta-analysis, conducted by Minasny and McBratney (2018), which reports a slight increase in AWC due to OM application (from 0.7 to $2 \mathrm{~mm}$ $100 \mathrm{~mm}^{-1}$ AWC for an increase of $\left.10 \mathrm{~g} \mathrm{C} \mathrm{kg}^{-1} \mathrm{OC}\right)$ as also found by Ankenbauer and Loheide (2017) (from 17 to $37 \mathrm{~mm} 100 \mathrm{~mm}^{-1}$ AWC for an increase of $150 \mathrm{~g} \mathrm{~kg}^{-1} \mathrm{OC}$ ).
Moreover, the parameters of Van Genuchten's retention model, when fitted to the experimental retention curves (Table 3 ), showed no statistically significant difference in mean values, but a clear trend could be detected in the saturated water content (Theta s). In fact, $\mathrm{WC}_{\mathrm{V}}$ at the air entry point showed increasing values along with the increase in SWRs concentrations, particularly in the 
Table 3 Soil water retention parameters, Van Genuchten model

\begin{tabular}{lllllll}
\hline Treatment & $\begin{array}{l}\text { Theta s } \\
\left(\mathrm{m}^{3} \mathrm{~m}^{-3}\right) \mathrm{m}^{-3}\end{array}$ & $\begin{array}{l}\text { Theta s } \\
\left(\mathrm{m}^{3} \mathrm{~m}^{-3}\right)\end{array}$ & $\begin{array}{l}\text { Air entry } \\
(\mathrm{cm})\end{array}$ & \multicolumn{1}{l}{$\begin{array}{l}n \\
-\end{array}$} & \multicolumn{1}{l}{\begin{tabular}{l}
\multicolumn{1}{l}{ AWC } \\
$\left(\mathrm{m}^{3} \mathrm{~m}^{-3}\right)$
\end{tabular}} \\
\hline C & $0.40 \pm 0.04$ & $0.12 \pm 0.01$ & $20.34 \pm 2.6$ & $2.26 \pm 0.05$ & $0.56 \pm 0.01$ & $0.30 \pm 0.04$ \\
WW0.5\% & $0.35 \pm 0.05$ & $0.12 \pm 0.01$ & $19.75 \pm 4.1$ & $2.20 \pm 0.07$ & $0.54 \pm 0.09$ & $0.25 \pm 0.04$ \\
WW1\% & $0.43 \pm 0.02$ & $0.13 \pm 0.01$ & $18.27 \pm 1.8$ & $2.24 \pm 0.39$ & $0.55 \pm 0.03$ & $0.32 \pm 0.03$ \\
WW2\% & $0.43 \pm 0.02$ & $0.13 \pm 0.01$ & $18.64 \pm 3.0$ & $2.01 \pm 0.17$ & $0.450 \pm 0.05$ & $0.32 \pm 0.04$ \\
BW0.5\% & $0.37 \pm 0.03$ & $0.11 \pm 0.01$ & $17.25 \pm 0.8$ & $2.17 \pm 0.20$ & $0.53 \pm 0.08$ & $0.27 \pm 0.02$ \\
BW1\% & $0.46 \pm 0.060$ & $0.14 \pm 0.01$ & $15.54 \pm 5.1$ & $1.91 \pm 0.33$ & $0.47 \pm 0.14$ & $0.33 \pm 0.06$ \\
BW2\% & $0.46 \pm 0.04$ & $0.13 \pm 0.00$ & $17.58 \pm 1.5$ & $2.27 \pm 0.52$ & $0.56 \pm 0.05$ & $0.36 \pm 0.05$ \\
\hline
\end{tabular}

The water retention curves $(n=3)$ in each treatment were interpolated with the RETC software (Van Genuchten et al. 1991) using the Van Genuchten's model (1980) in order to derive the retention parameters, i.e., air entry potential, Theta $\mathrm{s}$ (the saturated water content), Theta $\mathrm{r}$ (the residual water content), $n$ (pore size distribution index) and $m$ (the fitting coefficients) for treatments comparison
BW (14\%) in comparison with the WW (7\%) treatments. Another clearly detectable trend was observed in air entry values $(\mathrm{cm})$, i.e., the potential at which air passes through a previously saturated porous media. A decrease in air entry potential was observed in all SWRs-soil mixtures. This was particularly evident in the $1 \%$ treatments, especially in BW ( -10 and $-24 \%$ with respect to the control for WW and BW, respectively). The addition of SWRs slightly affected the slope of the retention curves. A more shallow slope of the curve, as described by Van Genuchten parameter in Table 3, characterized the WW2\% treatment $(-11 \%$ with respect to the control) and even more the BW1\% treatment ( $-16 \%$ with respect to the control).

\section{Slaking, aggregate stability and aggregate size distribution (ASD)}

According to the USDA stability classes, the slaking test results (Fig. 5) showed a limited slaking of SWRs-soil mixtures compared to the control soil. A significantly $(P<0.05)$ higher mean score was recorded in WW-soil mixtures (3.6) followed by BW-soil mixtures (2.9) and the control (2.0). Indeed, the increase of the concentration of SWRs reduced the slaking. Additionally, both SWRs types and concentrations proportionally and significantly $(P<0.05)$ increased the percentage of water-stable aggregates (WSA $>0.25 \mathrm{~mm}$ ) with respect to the control soil (Fig. 6). The average percentage of WSA in the SWRs-soil mixtures $(64.66 \%$ and
Fig. 5 Slaking tests of aggregates. Scores for the slaking tests of aggregates using USDA slaking test method in control soil (C), and in the different SWRs-soil mixtures (WW and $\mathrm{BW}$ residues) at $0.5,1$ and $2 \%$ concentrations. Average values $(n=3) \pm$ standard error, \pm 97.5 percentile point are shown

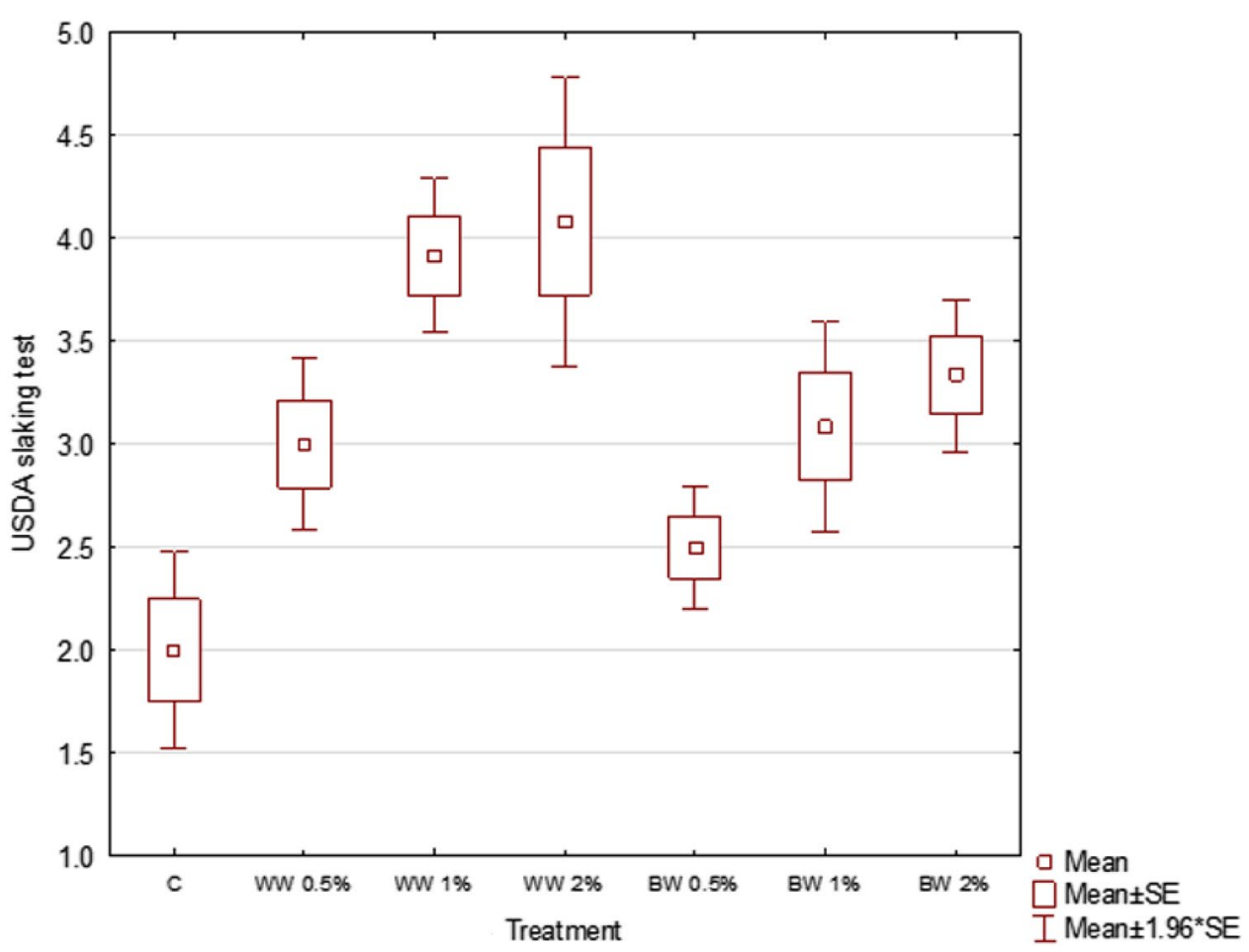


Fig. 6 Aggregate stability. Aggregate stability (\% of waterstable aggregates) in control soil (C) and in the SWRs-soil mixtures (WW and BW residues) at $0.5,1$ and $2 \%$ concentrations. Average values $(n=3) \pm$ standard error, \pm 97.5 percentile point are shown

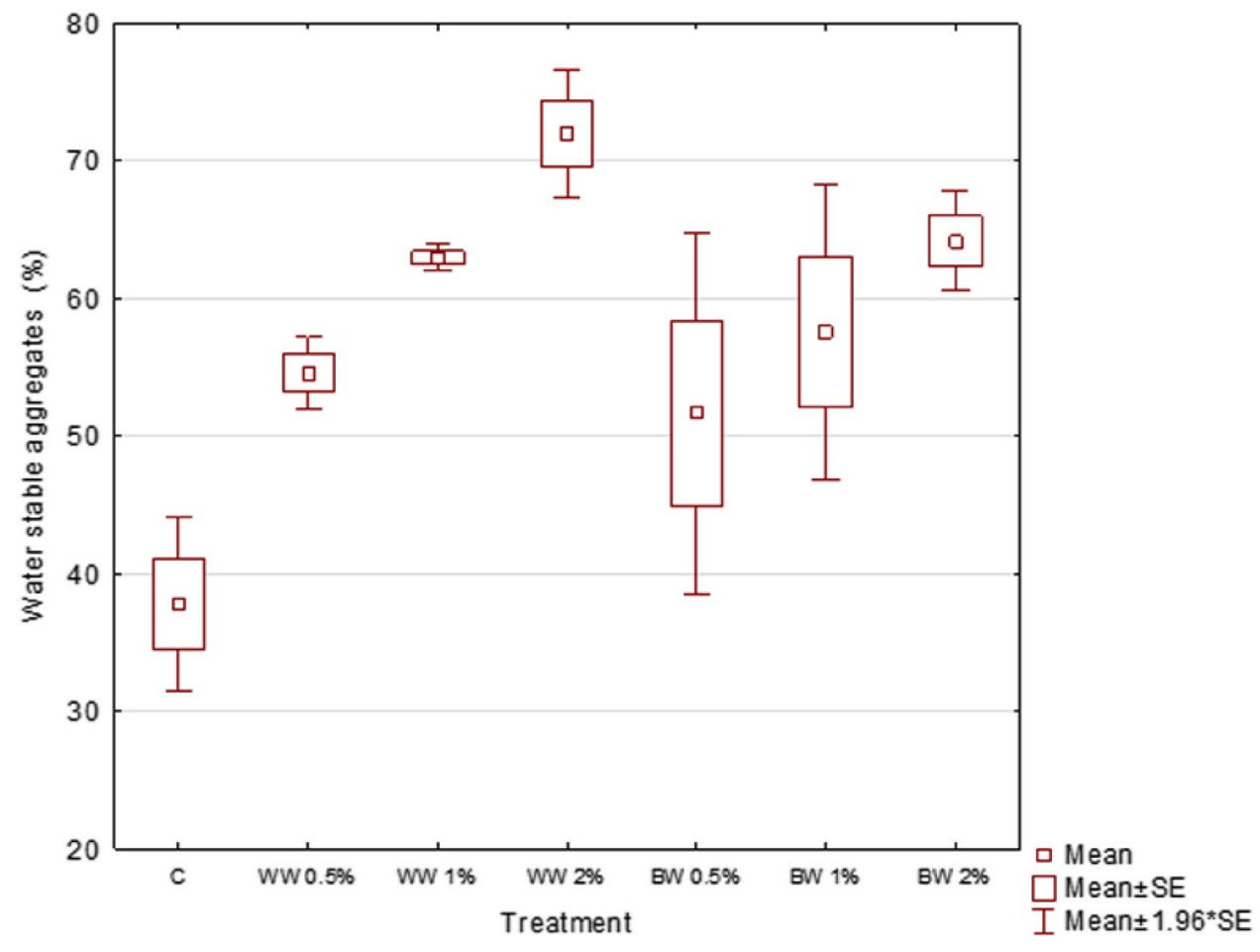

$57.81 \%$ in WW- and BW-soil mixtures, respectively) was higher than in the control $(37.82 \%)$. The percentages of WSA for $0.5,1$ and $2 \% \mathrm{WW}$-soil mixtures were $1.5,1.66$ and 1.95 times greater than the control, respectively; in the case of the BW treatments, WSA percentages were 1.36, 1.52 and 1.69 times greater than the control. Although the mean percentages of WSA were always higher in the WW than in the BW treatments, the differences between the two SWRs types were not statistically significant $(P<0.05)$ at any concentration.

The results showed a significant effect of SWRs application on different ASCs (Table 4), especially in the case of
WW. Control soil had significantly $(P<0.05)$ higher content of small aggregates in the 2.0-1.0, 1.0-0.5 and 0.5-0.25 mm ASCs. Generally, SWRs applications significantly increased the formation of larger aggregates $(>8.0,8.0-4.0$, and $4.0-2.0 \mathrm{~mm}$ ) as compared to the control. For example, $\mathrm{WW} 2 \%$ had a significantly higher content of $>8 \mathrm{~mm}$ aggregates, more than $57 \%$ of aggregates $>4 \mathrm{~mm}$ (Table 4 ), while in both SWRs-soil mixtures, the ASC 8.0-4.0 mm was $>24 \%$. Furthermore, ASC (4.0-2.0 mm) was mainly found in WW-soil mixtures ( 1 and $2 \%$ treatments) and in BW $0.5 \%$.

Regarding the dMWD (Table 4), both SWRs type and concentration had significant effects $(P<0.05)$. The dMWD

Table 4 Aggregate size distribution (ASD) and dry mean weight diameter (dMWD)

\begin{tabular}{lllllllll}
\hline Treatment & \multicolumn{1}{l}{ ADS (\%) in each ASC } & \multicolumn{1}{l}{$\begin{array}{l}\text { DMWD } \\
(\mathrm{mm})\end{array}$} \\
\cline { 2 - 8 } & $>8$ & $8-4$ & $4-2$ & $2-1$ & $1-0.5$ & $0.5-0.25$ & $<0.25$ & \\
\hline C & $12.31 \pm 2.27 \mathrm{~b}$ & $16.16 \pm 0.27 \mathrm{~b}$ & $10.75 \pm 1.32 \mathrm{abc}$ & $15.11 \pm 3.22 \mathrm{ab}$ & $15.63 \pm 0.34 \mathrm{a}$ & $20.41 \pm 2.49 \mathrm{ab}$ & $9.63 \pm 0.78 \mathrm{ab}$ & $3.20 \pm 0.20 \mathrm{c}$ \\
WW 0.5\% & $16.59 \pm 4.67 \mathrm{~b}$ & $26.41 \pm 2.00 \mathrm{a}$ & $14.23 \pm 0.18 \mathrm{a}$ & $13.29 \pm 0.59 \mathrm{~b}$ & $13.18 \pm 1.36 \mathrm{ab}$ & $10.91 \pm 2.76 \mathrm{~cd}$ & $5.38 \pm 1.89 \mathrm{c}$ & $4.35 \pm 0.33 \mathrm{~b}$ \\
WW 1\% & $17.60 \pm 3.78 \mathrm{~b}$ & $28.35 \pm 6.97 \mathrm{a}$ & $13.25 \pm 1.75 \mathrm{abc}$ & $13.67 \pm 3.13 \mathrm{ab}$ & $10.71 \pm 3.36 \mathrm{bc}$ & $10.01 \pm 1.93 \mathrm{~d}$ & $6.40 \pm 0.76 \mathrm{bc}$ & $4.54 \pm 0.63 \mathrm{ab}$ \\
WW 2\% & $26.42 \pm 0.59 \mathrm{a}$ & $31.24 \pm 4.55 \mathrm{a}$ & $10.39 \pm 2.35 \mathrm{c}$ & $6.67 \pm 1.67 \mathrm{c}$ & $6.28 \pm 2.47 \mathrm{c}$ & $12.26 \pm 2.80 \mathrm{~cd}$ & $6.74 \pm 1.92 \mathrm{abc} 5.56 \pm 0.63 \mathrm{a}$ \\
BW 0.5\% & $11.71 \pm 2.32 \mathrm{~b}$ & $24.18 \pm 2.33 \mathrm{ab}$ & $14.26 \pm 0.86 \mathrm{a}$ & $8.13 \pm 0.74 \mathrm{c}$ & $12.00 \pm 1.18 \mathrm{ab}$ & $19.63 \pm 1.53 \mathrm{ab}$ & $10.09 \pm 0.39 \mathrm{a}$ & $3.58 \pm 0.03 \mathrm{bc}$ \\
BW 1\% & $12.16 \pm 1.76 \mathrm{~b}$ & $26.32 \pm 0.45 \mathrm{a}$ & $9.61 \pm 0.70 \mathrm{bc}$ & $7.60 \pm 1.08 \mathrm{c}$ & $10.09 \pm 0.44 \mathrm{bc}$ & $24.74 \pm 0.69 \mathrm{a}$ & $9.49 \pm 1.15 \mathrm{ab}$ & $3.62 \pm 0.20 \mathrm{bc}$ \\
BW 2\% & $13.02 \pm 0.53 \mathrm{~b}$ & $29.99 \pm 1.01 \mathrm{a}$ & $10.34 \pm 0.97 \mathrm{bc}$ & $9.78 \pm 1.02 \mathrm{bc}$ & $13.66 \pm 0.28 \mathrm{ab}$ & $16.24 \pm 1.00 \mathrm{bcd}$ & $6.97 \pm 0.94 \mathrm{abc} 3.99 \pm 0.31 \mathrm{bc}$ \\
\hline
\end{tabular}

Aggregate size distribution (ASD) is calculated as the ratio between the dry weight of aggregates in a specific aggregate size class (ASC, mm) and the total aggregates dry weight, expressed as percentage. Mean values $(n=3) \pm$ standard deviations are shown for the SWRs-soil mixtures (BW and WW residues) at $0.5,1$ and $2 \%$ concentrations and the control, with significant differences between treatments identified by the Tukey test at $P<0.05$, marked by letters 
was significantly higher in wool-treated soil in the following order: WW $(4.82 \pm 0.49 \mathrm{~mm})>\mathrm{BW}(3.73 \pm 0.18 \mathrm{~mm})$ $>$ control $(3.20 \pm 0.24 \mathrm{~mm})$. The dMWD was proportional to the SWRs concentrations; values of dMWD were significantly higher at the highest WW concentration $(2 \%, 5.56 \pm 0.72 \mathrm{~mm})$ compared to the lower ones $(1 \%$, $4.54 \pm 0.73 \mathrm{~mm}$, and $0.5 \%, 4.35 \pm 0.38 \mathrm{~mm}$ ). No significant differences were recorded among BW treatments. Also, no significant differences were found between the lower concentrations $(0.5 \%$ and $1 \%)$ in the two SWRs types. The significant positive effect of SWRs on the formation of large aggregates, aggregate stability and limited slaking, compared to the control treatment, might be attributed to the presence of SWRs' organic carbon. Carbon in soil aggregates increases their stability since it decomposes slowly or not at all (Beare et al. 1994). Other authors reported the positive effect of $\mathrm{OM}$ on the formation of large aggregates (Šimanský et al. 2008; de Melo et al. 2019) and in maintaining their stability in most agricultural soils (Le Guillou et al. 2011; de Melo et al. 2019). Furthermore, the release of soluble salts in SWRs could help to improve soil aggregates formation and stability by promoting flocculation of clay minerals (Lakhdar et al. 2010). Another reason for the increased aggregate stability of SWRs-treated soil could be the reduction in $\mathrm{pH}$ (as explained below). Since aggregate stability increases in acid soils, the aggregates under alkaline conditions are not stable because of the higher solubility of humic substances (Chenu et al. 2000).

\section{Saturated hydraulic conductivity}

SWRs application increased Ksat (Fig. 7) compared to the control, but because of the high variability, no significant difference was observed. Nevertheless, some clear trends can be highlighted: with respect to control treatment $\left(11.5 \pm 11.4 \mathrm{~mm} \mathrm{~h}^{-1}\right)$, Ksat increased on average by $107 \%$ in WW $\left(108.2 \pm 53.9 \mathrm{~mm} \mathrm{~h}^{-1}\right)$ and by $250 \%$ in BW $\left(249.8 \pm 204.1 \mathrm{~mm} \mathrm{~h}^{-1}\right)$ treatments. In WW-soil mixtures, the highest Ksat values $\left(149.6 \pm 136.4 \mathrm{~mm} \mathrm{~h}^{-1}\right)$ were observed at the lowest concentration $(0.5 \%)$ and were lower at higher concentrations while, in BW-soil mixtures Ksat values $\left(439.1 \pm 593.6 \mathrm{~mm} \mathrm{~h}^{-1}\right)$ increased at the medium concentration (1\%). On average SWRs provided 96\% Ksat increase than the control. It was observed that at low concentrations, SWRs reduced soil BD and enhanced permeability and, thus, Ksat. At higher concentrations, they slightly decreased Ksat, probably because of finer particles entrapment. However, the values were similar to those measured in the field $\left(97.2 \pm 44.9 \mathrm{~mm} \mathrm{~h}^{-1}\right)$, suggesting that the control soil undergoes significant compaction after being transferred in the pots. This is not surprising given the high sand content, very low organic carbon content and weak structure observed in the field. Another reason for the increased Ksat could be that the high values of dMWD indicate high water permeability and air capacity due to the formation of larger volumes of macro- and meso-pores (Kay 1998).
Fig. 7 Saturated hydraulic conductivity. Values of saturated hydraulic conductivity (Ksat) $\left(\mathrm{mm} \mathrm{h}^{-1}\right)$ : in control soil $(\mathrm{C})$, in the field where the soil was $\operatorname{dug}(\mathrm{F})$ and in the different SWRs-soil mixtures (WW and $\mathrm{BW}$ residues) at $0.5,1,2 \%$ concentrations. Average values $(n=3) \pm$ standard error, \pm 97.5 percentile point are shown

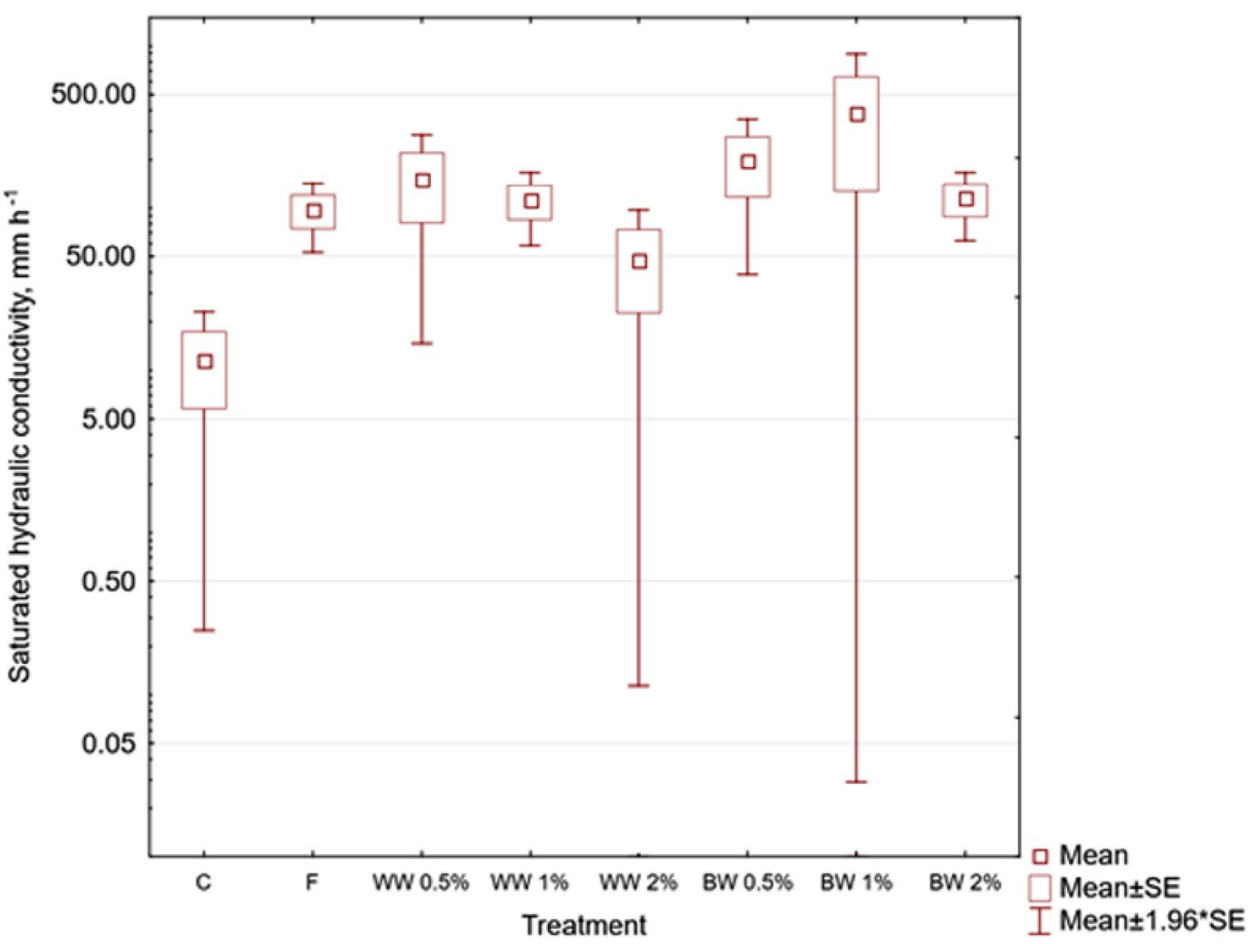




\section{Rainwater balance}

Results of the rainwater balance showed significant $(P<0.05)$ differences in water storage and drainage between the beginning and end of the experiment. The first rainfall event $(23.4 \mathrm{~mm}$ over $13 \mathrm{~h}$ with a maximum intensity of $\left.8.8 \mathrm{~mm} \mathrm{~h}^{-1}\right)$ highlighted the significantly $(P<0.05)$ higher water storage $(84.3 \%)$ and lower or negligible drainage of the control compared to the SWRs-soil mixtures (Fig. 8a). No difference in water storage or drainage was observed between 1 and $2 \%$ concentration both in $\mathrm{WW}$ and $\mathrm{BW}$ soil mixtures. When the $\mathrm{WW}$ and $\mathrm{BW}$ soil mixtures at $2 \%$ concentration were compared, significant differences were observed: in BW2\% water storage was lower $(P<0.01)$ and drainage was higher than in WW2\% (water storage: $50.37 \%$ vs $62.15 \%$ and drainage: $26.2 \%$ vs $19.12 \%$ ). During the second rainfall event ( $27.8 \mathrm{~mm}$ over 4 days, with a maximum intensity of $5.6 \mathrm{~mm} \mathrm{~h}^{-1}$ ), both SWRs-soil mixtures showed little differences in water storage among the different concentrations (Fig. 8b). Values were slightly lower than in the first rainfall event. The BW-soil mixtures showed on average higher water storage (38.0\%) than WW-soil mixtures and the control (35\% and $30.3 \%$, respectively). In the third rainfall event $(3.8 \mathrm{~mm}$ over $11 \mathrm{~h}$, with a maximum intensity of $5.6 \mathrm{~mm} \mathrm{~h}^{-1}$ ) (Fig. 8c), the stored water was significantly higher in both SWRs-soil mixtures with respect to the control. As for the overall balance (Fig. 8d) of the three rainfall events $(55 \mathrm{~mm})$, mean water storage (as percentage of total precipitation) was significantly higher $(P<0.05)$ in the control soil $(52.44 \pm 5.9 \%)$ than in the WW-soil mixtures $(42.43 \pm 2.7 \%)$ and the BW-soil mixtures $(41.6 \pm 2.0 \%)$.
In terms of water drainage (Fig. 8e-h), the control soil was significantly $(P<0.05)$ lower $(6.1 \pm 2.4 \%)$ than any SWRs-soil treatment. In the case of WW-soil mixtures, the $1 \%$ treatment percolated nearly twice as much $(17.7 \pm 0.5 \%)$ as the $2 \%(10.1 \pm 1.3 \%)$. The two BW-soil mixtures were not significantly different from each other $(18.6 \pm 2.2 \%$ and $18.3 \pm 0.5 \%$ for BW $1 \%$ and BW $2 \%$, respectively), but they were both significantly $(P<0.05)$ different from the WW2\%.

The increase in percolation of SWRs-soil mixture could be attributed to the addition of OM which indirectly improves soil porosity that, in turn, promotes water infiltration and enhances salt leaching (Bhattacharyya et al. 2010). This was confirmed by the increase in Ksat and leachate salinity collected after the heavy rainfall events. Higher Ksat and drainage values can be explained by the formation of large and stable aggregates that may cause macro- and mesopores (Kay 1998; Shepherd et al. 2006). In this regard, for instance, a thin soil section treated with OC examined by Giusquiani et al. (1995) showed the presence of more elongated pores $(>50 \mu \mathrm{m})$ compared to untreated soil. Moreover, the observed decrease in air entry potential of SWRs-soil mixture suggests a modification of the pore system, with larger and more continuous pores. The rainwater balance results were coherent with the Ksat values that were lower in the control soil (the lowest drainage) and higher in BW- and $\mathrm{WW}-$ soil mixtures at medium and low concentration $(0.5 \%$ and $1 \%$ showed the highest drainage). Therefore, the results suggest that SWRs produce a slight modification making the pores system larger and more continuous, thus, increasing the water movement. Consequently, SWRs could be applied to enhance soil infiltration capacity, to reduce surface runoff
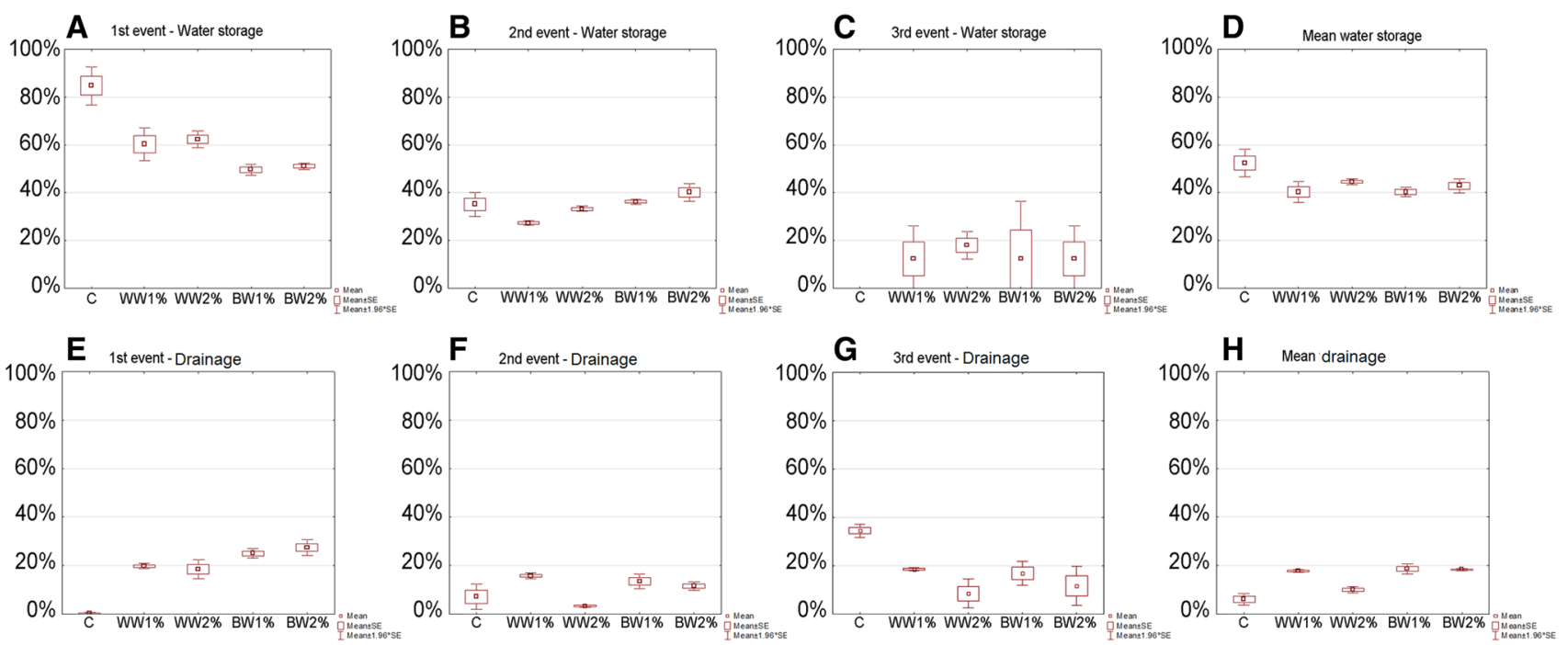

Fig. 8 Rainwater balance. Water storage (a-c) and drainage $(\mathbf{e}-\mathbf{g})$ as percentages of total precipitation in the three rainfall events and as average of the water storage (d) and drainage (h): in control soil (C)

and in the different SWRs-soil mixtures (WW and BW residues) at $0.5,1$ and $2 \%$ concentrations 
and soil erosion under heavy and intensive rainfall, but they are not suitable for effective rainwater conservation.

\section{Salinity and pH of soil and leachate}

During the rain water balance experiment, soil and leachate samples were collected, then salinity and $\mathrm{pH}$ were determined. The SWRs-soil mixtures recorded higher leachate salinity (Table 5a), regardless of SWRs type. Leachate salinity in WW1\%, WW2\%, BW $1 \%$ and BW2\% were 3.2 , 3.8, 2.8 and 1.02 times higher than the control, respectively. Moreover, the leachate salinity in WW-soil mixtures, at both concentrations, was significantly $(P<0.05)$ higher than the leachate salinity in BW-soil mixtures. Both SWRs types affected leachate $\mathrm{pH}$ (Table 5a) which was significantly lower than in the control $(8.2 \pm 0.46)$. The lowest $\mathrm{pH}$ value was recorded in BW2\% $(6.6 \pm 0.51)$, while sub-alkaline values were recorded in BW1\%, WW $1 \%$ and WW2\% with no statistically significant differences among them.

Soil salinity (Table $5 b$ ) differed according to SWRs types, concentrations and sampling time. As compared to the control, BW1\% and BW2\% significantly increased soil salinity when they were freshly mixed with the soil. Instead, WW at the same concentrations did not differ from the control. One month after the SWRs addition, soil salinity significantly increased in WW-soil mixtures, especially at higher WW concentrations. In BW-soil mixtures, soil salinity showed a moderate, but still significant increase only in BW1\%, whilst BW2\% showed a decreasing trend $(-19 \%)$ with respect to the fresh mixture. At the end of the experiment, the values in all treatments did not significantly change with the exception of BW2\% which showed a marked decrease.
Soil $\mathrm{pH}$ was more affected by SWRs type than concentration (Table 5b). A strong $\mathrm{pH}$ reduction was recorded for the mixtures just after mixing BW with the soil $(3.8 \pm 0.02$ and $3.2 \pm 0.01$ in BW1\% and BW2\%, respectively, vs $6.25 \pm 0.20$ for control). Instead, mixing WW with the soil at both concentrations had no effects. After 1 month and at the end of the experiment, similar trends were observed; taking soil $\mathrm{pH}$ of the fresh mixture as a reference, soil $\mathrm{pH}$ increased in BW-soil mixtures $(5.32 \pm 0.11$ and $4.64 \pm 0.27$ for $\mathrm{BW} 1 \%$ and BW2\%, respectively), and decreased in WW-soil mixtures $(5.08 \pm 0.12$ and $5.59 \pm 0.16$ for $\mathrm{WW} 1 \%$, WW $2 \%$, respectively) while it did not change in the control $(6.12 \pm 0.09)$.

The significant $\mathrm{pH}$ reduction of SWRs-soil mixtures and leachate (especially in $\mathrm{BW}$ ) might be due to the acid treatment of carbonization, to microbial $\mathrm{CO}_{2}$, and to the release of organic acids with the displacement of exchangeable $\mathrm{H}^{+}$ions to the soil solution (Nelson et al. 1998). The obtained results are in accordance with many studies claiming that soil organic amendment leads to a decrease in $\mathrm{pH}$ (Bai et al. 2013). The increased soil and leachate salinity of the SWRs-amended soil could be due to the organic compounds biodegradation and the release of soluble minerals (Zheljazkov 2005; Bhavsar et al. 2016; Ghosh and Devi 2019) which increase electrolytes concentration in the soil solution. Several authors (Gupta and Sharma 2014; Ordiales et al. 2016) reported that the soil salinity increased with the wool addition due to $\mathrm{Na}$ liberation. The chemical analysis of both WW and BW (Table 2), showed that they contain significant of $\mathrm{Na}, \mathrm{N}, \mathrm{S}$, $\mathrm{K}, \mathrm{P}, \mathrm{Mg}$, and $\mathrm{Ca}$. Also the results of other studies (Böhme et al. 2008; Suruchi et al. 2014; Zheljazkov et al. 2009) report that wool-waste retains significant concentrations of $\mathrm{P}, \mathrm{Ca}, \mathrm{K}, \mathrm{Cu}, \mathrm{Zn}$, and $\mathrm{Mn}$.

Table 5 Salinity and $\mathrm{pH}$ of leachate and soil

\begin{tabular}{|c|c|c|c|c|c|c|c|c|}
\hline \multirow[t]{3}{*}{ Treatments } & \multicolumn{2}{|c|}{ (a) Leachate analysis } & \multicolumn{6}{|l|}{ (b) Soil analysis } \\
\hline & \multirow[t]{2}{*}{$\mathrm{EC}\left(\mathrm{dS} \mathrm{m}{ }^{-1}\right)$} & \multirow[t]{2}{*}{$\mathrm{pH}$} & \multicolumn{3}{|l|}{$\overline{\mathrm{EC}\left(\mathrm{dS} \mathrm{m} \mathrm{m}^{-1}\right)}$} & \multicolumn{3}{|l|}{$\mathrm{pH}$} \\
\hline & & & $\begin{array}{l}\text { At the begin- } \\
\text { ning }\end{array}$ & After 1 month & $\begin{array}{l}\text { At the end of } \\
\text { experiment }\end{array}$ & $\begin{array}{l}\text { At the begin- } \\
\text { ning }\end{array}$ & After 1 month & $\begin{array}{l}\text { At the end of } \\
\text { experiment }\end{array}$ \\
\hline $\mathrm{C}$ & $2.20 \pm 0.55 \mathrm{c}$ & $8.20 \pm 0.40 \mathrm{a}$ & $0.10 \pm 0.01 \mathrm{c}$ & $0.11 \pm 0.01 \mathrm{c}$ & $0.12 \pm 0.01 \mathrm{~b}$ & $6.25 \pm 0.17 b$ & $6.25 \pm 0.17 \mathrm{a}$ & $6.12 \pm 0.07 \mathrm{a}$ \\
\hline WW $1 \%$ & $7.14 \pm 1.20 \mathrm{ab}$ & $7.29 \pm 0.22 b c$ & $0.11 \pm 0.01 \mathrm{c}$ & $0.84 \pm 0.07 \mathrm{~b}$ & $0.84 \pm 0.07 \mathrm{a}$ & $6.74 \pm 0.11 \mathrm{a}^{*}$ & $6.19 \pm 0.18 \mathrm{ab}$ & $5.08 \pm 0.10 b^{*}$ \\
\hline WW 2\% & $8.61 \pm 0.86 \mathrm{a}$ & $7.38 \pm 0.11 \mathrm{~b}$ & $0.16 \pm 0.01 \mathrm{c}$ & $1.26 \pm 0.20 \mathrm{a}$ & $0.31 \pm 0.28 \mathrm{a}$ & $6.72 \pm 0.03 \mathrm{a}$ & $4.84 \pm 0.50 \mathrm{~d}$ & $5.59 \pm 0.13 b$ \\
\hline BW1\% & $6.16 \pm 0.14 b$ & $7.60 \pm 0.11 \mathrm{ab}$ & $0.85 \pm 0.01 \mathrm{~b}$ & $1.0 \pm 0.1 \mathrm{ab}$ & $1.10 \pm 0.17 \mathrm{a}$ & $3.87 \pm 0.01 \mathrm{c}$ & $6.09 \pm 0.57 b$ & $5.32 \pm 0.09 \mathrm{~b}$ \\
\hline BW2\% & $2.29 \pm 0.33 \mathrm{c}$ & $6.58 \pm 0.44 \mathrm{c}$ & $1.58 \pm 0.12 \mathrm{a}^{*}$ & $1.28 \pm 0.24 \mathrm{a}$ & $0.88 \pm 0.05 \mathrm{a}^{*}$ & $3.20 \pm 0.01 \mathrm{~d}$ & $5.90 \pm 0.86 \mathrm{c}$ & $4.64 \pm 0.23 \mathrm{c}$ \\
\hline
\end{tabular}

Salinity by electric conductivity (EC) and $\mathrm{pH}$ of leachate (a) and soil (b) from the rainwater balance experiment in the control (C) and SWRssoil mixtures (BW and WW residues at 1 and $2 \%$ concentrations at the beginning of the experiment, after 1 month and at the end of the experiment. Mean values $(n=3) \pm$ standard deviations are shown with significant differences between treatments identified by the Tukey test at $P<0.05$ marked by letters. * indicates a significant difference between the value at the beginning and end of the experiment given by the $T$ test for independent samples within the treatment at $P<0.05$ 


\section{Conclusions}

The effects of SWRs on soil physical and hydraulic properties were found to depend on the quantity and type of SWRs applied. Despite the potential of SWRs to increase WHC and AWC of the soil because of their absorption properties, the results of rain water balance showed higher drainage and less rainwater storage in the three rainfall events, likely due to modifications of the pore system by mixing wool residues in the soil. However, soil physical properties improved notably by an increase of large size and water-stable aggregates, influencing bulk density, porosity and Ksat. SWRs could thus be successfully applied to enhance physical and chemical soil properties to improve soil functions as soil infiltration capacity and reduce soil erosion risk. Nevertheless, further research is required to study the wide range of effects (e.g., chemical, physical and hydrological) of SWRs application on other soil types (e.g., finer textured soils) and in field conditions.

Acknowledgements The authors are grateful to Carbofin s.r.l. (a wool scouring company) for providing the SWRs used in the experiments. Thanks are also extended to Dr. Claudio Cantini of CNR-IVALSA for providing the soil and to Francesco Sabatini and Mario Lanini of CNR-IBIMET for the technical support. The authors also thank $\mathrm{Mr}$ Antonio Mauro, R.S. Ricerche Servizi SRL, for his useful suggestions and comments.

Funding information Dr. Abdallah was supported by the National Research Council of Italy and funded by the Ministry of Foreign Affairs and International Cooperation (MAECI) through the training multi-sectoral program (DIPLOMAZIA2). https://www.cnr.it/en/diplo mazia2-program.

\section{Compliance with ethical standards}

Conflict of interest The authors declare that they have no conflict of interest.

Open Access This article is distributed under the terms of the Creative Commons Attribution 4.0 International License (http://creativeco mmons.org/licenses/by/4.0/), which permits unrestricted use, distribution, and reproduction in any medium, provided you give appropriate credit to the original author(s) and the source, provide a link to the Creative Commons license, and indicate if changes were made.

\section{References}

Alagöz Z, Yilmaz E (2009) Effects of different sources of organic matter on soil aggregate formation and stability: a laboratory study on a Lithic Rhodoxeralf from Turkey. Soil Tillage Res 103:419-424. https://doi.org/10.1016/J.STILL.2008.12.006

Ankenbauer KJ, Loheide SP (2017) The effects of soil organic matter on soil water retention and plant water use in a meadow of the Sierra Nevada, CA. Hydrol Process 31:891-901. https://doi. org/10.1002/hyp.11070
Bai Y, Gu C, Tao T, Chen G, Shan Y (2013) Straw incorporation increases solubility and uptake of cadmium by rice plants. Acta Agric Scand Sect B-Soil Plant Sci 63:193-199. https://doi. org/10.1080/09064710.2012.743582

Beare MH, Hendrix PF, Cabrera ML, Coleman DC (1994) Aggregate-protected and unprotected organic matter pools in conventional- and no-tillage soils. Soil Sci Soc Am J 58:787. https://doi. org/10.2136/sssaj1994.03615995005800030021x

Bhattacharyya R, Prakash V, Kundu S, Srivastva AK, Gupta HS, Mitra S (2010) Long term effects of fertilization on carbon and nitrogen sequestration and aggregate associated carbon and nitrogen in the Indian sub-Himalayas. Nutr Cycl Agroecosystems 86:1-16. https ://doi.org/10.1007/s10705-009-9270-y

Bhavsar P, Zoccola M, Patrucco A, Montarsolo A, Mossotti R, Rovero G, Giansetti M, Tonin C (2016) Superheated water hydrolysis of waste wool in a semi-industrial reactor to obtain nitrogen fertilizers. ACS Sustain Chem Eng 4:6722-6731. https://doi. org/10.1021/acssuschemeng.6b01664

Böhme M, Schevchenko J, Pinker I, Herfort S (2008) Cucumber grown in sheepwool slabs treated with biostimulator compared to other organic and mineral substrates. Acta Hortic 779:299-306. https ://doi.org/10.17660/ActaHortic.2008.779.36

Chenu C, Le Bissonnais Y, Arrouays D (2000) Organic matter influence on clay wettability and soil aggregate stability. Soil Sci Soc Am J 64:1479-1486. https://doi.org/10.2136/sssaj2000.6441479x

Danielson RE, Sutherland PL (1986) Porosity. In: Klute A (ed) Methods of soil analysis, part I. Physical and mineralogical methods. Agronomy monograph no. 9. American Society of AgronomySoil Science Society of America, Madison, pp 443-461

de Melo TR, Figueiredo A, Machado W, Tavares Filho J (2019) Changes on soil structural stability after in natura and composted chicken manure application. Int J Recycl Org Waste Agric. https ://doi.org/10.1007/s40093-019-0250-1

FAO (2015) Towards a water critical perspectives for policy-makers. Food and Agriculture Organization of the United Nations, Rome

Franzluebbers A (2002) Water infiltration and soil structure related to organic matter and its stratification with depth. Soil Tillage Res 66:197-205. https://doi.org/10.1016/S0167-1987(02)00027-2

Ghosh M, Devi A (2019) Assessment of crop growth, soil properties and crop yield in an upland acidic soil with inorganic fertilizer blended with organic amendments in summer rice cropping seasons. Int J Recycl Org Waste Agric. https://doi.org/10.1007/s4009 3-019-0252-z

Giusquiani PL, Pagliai M, Gigliotti G, Businelli D, Benetti A (1995) Urban waste compost: effects on physical, chemical, and biochemical soil properties. J Environ Qual 24:175-182. https://doi. org/10.2134/jeq1995.00472425002400010024x

Gupta S, Sharma A (2014) Evaluation of plant yield, macro and micronutrients concentration in spinach (Spinacia oleracea L.) plant tissue as well as in soil amended with hair as fertilizer. Int J Chem Sci 12:73-82

Hayashi M, Quinton WL (2004) A constant-head well permeameter method for measuring field-saturated hydraulic conductivity above an impermeable layer. Can J Soil Sci 84:255-264. https:// doi.org/10.4141/S03-064

Hillel D (2004) Introduction to environmental soil physics. Elsevier, Amsterdam

Jaroszuk M, Słowińska-Jurkiewicz A (2005) Characteristics of basic water-air properties of horticultural substrates used in container cultivation. Zesz Probl Post Nauk Roln 504:105. https://doi. org/10.1016/j.eja.2003.08.001

Kay BD (1998) Soil structure and organic carbon: a review. In: Lal R, Kimble JM, Follett RF, Stewart BA (eds) Soil processes and the carbon cycle. CRC Press, Boca Raton, pp 169-197 
Lakhdar A, Scelza R, Scotti R, Rao MA, Jedidi N, Gianfreda L, Abdelly C (2010) The effect of compost and sewage sludge on soil biologic activities in salt affected soil. J Soil Sci Plant Nutr 10:40-47. https://doi.org/10.4067/S0718-27912010000100005

Le Guillou C, Angers DA, Leterme P, Menasseri-Aubry S (2011) Differential and successive effects of residue quality and soil mineral $\mathrm{N}$ on water-stable aggregation during crop residue decomposition. Soil Biol Biochem 43:1955-1960. https://doi.org/10.1016/j.soilb io.2011.06.004

Lee SH, Yoo SH, Choi JY, Bae S (2017) Assessment of the impact of climate change on drought characteristics in the Hwanghae plain, North Korea using time series SPI and SPEI: 1981-2100. Water (Switzerland). https://doi.org/10.3390/w9080579

Mbarek HB, Mahmoud IB, Chaker R, Rigane H, Maktouf S, Arous A, Soua N, Khlifi M, Gargouri K (2019) Change of soil quality based on humic acid with date palm compost incorporation. Int J Recycl Org Waste Agric. https://doi.org/10.1007/s40093-019-0254-X

McNeil SJ, Sunderland MR, Zaitseva LI (2007) Closed-loop wool carpet recycling. Resour Conserv Recycl 51:220-224. https://doi. org/10.1016/j.resconrec.2006.09.006

Mellek JE, Dieckow J, da Silva VL, Favaretto N, Pauletti V, Vezzani FM, de Souza JLM (2010) Dairy liquid manure and no-tillage: physical and hydraulic properties and carbon stocks in a Cambisol of Southern Brazil. Soil Tillage Res 110:69-76. https://doi. org/10.1016/j.still.2010.06.005

Minasny B, McBratney AB (2018) Limited effect of organic matter on soil available water capacity. Eur J Soil Sci 69:39-47. https://doi. org/10.1111/ejss.12475

Mubarak AR, Ragab OE, Ali AA, Hamed NE (2009) Short-term studies on use of organic amendments for amelioration of a sandy soil. Afr J Agric Res 4:621-627

Murray J, Frost J, Wang Y (2000) Behavior of a sandy silt reinforced with discontinuous recycled fiber inclusions. Transp Res Rec J Transp Res Board 1714:9-17. https://doi.org/10.3141/1714-02

Nelson PN, Baldock JA, Oades JM (1998) Changes in dispersible clay content, organic carbon content, and electrolyte composition following incubation of sodic soil. Aust J Soil Res 36:883-897. https ://doi.org/10.1071/S98024

Nowak JS (2005) Air-water properties of growing media. Zesz Probl Post Nauk Roln 504:175 [In Polish]

Oguntade OA, Olagbenro TS, Odusanya OA, Olagunju SO, Adewusi KM, Adegoke AT (2018) Assessment of composted kitchen waste and poultry manure amendments on growth, yield and heavy metal uptake by jute mallow Corchorus olitorius Linn. Int J Recycl Org Waste Agric 8:187-195. https://doi.org/10.1007/ s40093-018-0232-8

Ordiales E, Gutiérrez JI, Zajara L, Gil J, Lanzke M (2016) Assessment of utilization of sheep wool pellets as organic fertilizer and soil amendment in processing tomato and broccoli. Mod Agric Sci Technol 2:20-35. https://doi.org/10.15341/ $\operatorname{mast}(2375-9402) / 02.02 .2016 / 003$

Reynolds WD, Elrick DE, Topp GC (1983) A re-examination of the constant head well permeameter method for measuring saturated hydraulic conductivity above the water table. Soil Sci 136:250 268. https://doi.org/10.1097/00010694-198310000-00008

Rigby H, Dowding A, Fernandes A, Humphries D, Petch R, Reynolds C, Rose M, Smith S (2015) Organic contaminant content and physico-chemical characteristics of waste materials recycled in agriculture. Agriculture 5:1289-1328. https://doi.org/10.3390/ agriculture5041289

Savinov NO (1936) Soil physics. Sielchozgiz Press, Moscow

Shepherd MA, Harrison R, Webb J (2006) Managing soil organic matter-implications for soil structure on organic farms. Soil Use Manag 18:284-292. https://doi.org/10.1111/j.1475-2743.2002. tb00270.x
Šimanský V, Tobiašová E, Chlpík J (2008) Soil tillage and fertilization of Orthic Luvisol and their influence on chemical properties, soil structure stability and carbon distribution in water-stable macro-aggregates. Soil Tillage Res 100:125-132. https://doi. org/10.1016/j.still.2008.05.008

Soil Survey Division Staff (2017) Soil survey manual, United States Department of Agriculture, handbook, vol 18. United States Department of Agriculture, Washington, pp 120-125

Soil Survey Staff (2014) Keys to soil taxonomy, 12th edn. United States Department of Agriculture, Natural Resources Conservation Service, Lincoln, pp 123-287

Soilmoisture Equipment Corp. (2012) Operating instructions: Guelph permeameter. Soilmoisture Equipment Corp, Goleta, pp 3-57

StatSoft Inc (2014) Statistica (Data Analysis Software System), Version 12

Suruchi G, Anshumala S, Sarika S, Narindra B (2014) Growth, macro and micronutrient concent- ration in clusterbean (cyamopsis tetragonoloba), plant tissue as well as in soil when amended with wool as fertilizer. J Environ Res Dev 8:607-613

US EPA (1996) Soil screening guidance: technical background document. Office of solid waste and emergency response. United States Environmental Protection Agency, Washington, p 447

USDA (1999) Soil quality test kit guide. United States Department of Agriculture, Agricultural Research Service, Natural Resources Conservation Service, Soil Quality Institute, Washington, pp 1-88. https://doi.org/10.1037/t15144-000

Van Genuchten MT (1980) A closed-form equation for predicting the hydraulic conductivity of unsaturated soils. Soil Sci Soc Am J 44:892-898. https://doi.org/10.2136/sssaj1980.036159950044000 $50002 x$

Van Genuchten MTH, Leij FJ, Yates SR (1991) The RETC code for quantifying the hydraulic functions of unsaturated soils. US Environmental Protection Agency, Washington EPA/600/2-91/065 (NTIS 92-119668)

Verville RR (1996) Organic feedstock generators team up with local farmers. Biocycle 37:58-61

Wasaya A, Zhang X, Fang Q, Yan Z (2018) Root phenotyping for drought tolerance: a review. Agronomy 8:241. https://doi. org/10.3390/agronomy8110241

Williams A, Hunter MC, Kammerer M, Kane DA, Jordan NR, Mortensen DZ, Smith RG, Snapp S, Davis AS (2016) Soil water holding capacity mitigates downside risk and volatility in US rainfed maize: time to invest in soil organic matter? PLoS One 11:e0160974. https://doi.org/10.1371/journal.pone.0160974

Zheljazkov VD (2005) Assessment of wool waste and hair waste as soil amendment and nutrient source. J Environ Qual 34:2310. https:// doi.org/10.2134/jeq2004.0332

Zheljazkov VD, Stratton GW, Sturz T (2008) Uncomposted wool and hair-wastes as soil amendments for high-value crops. Agron J 100:1605-1614. https://doi.org/10.2134/agronj2007.0214

Zheljazkov VD, Stratton GW, Pincock J, Butler S, Jeliazkova EA, Nedkov NK, Gerard PD (2009) Wool-waste as organic nutrient source for container-grown plants. Waste Manag 29:2160-2164. https:// doi.org/10.1016/j.wasman.2009.03.009

Zoccola M, Montarsolo A, Mossotti R, Patrucco A, Tonin C (2015) Green hydrolysis as an emerging technology to turn wool waste into organic nitrogen fertilizer. Waste Biomass Valoriz 6:891-897. https://doi.org/10.1007/s12649-015-9393-0

Publisher's Note Springer Nature remains neutral with regard to jurisdictional claims in published maps and institutional affiliations. 